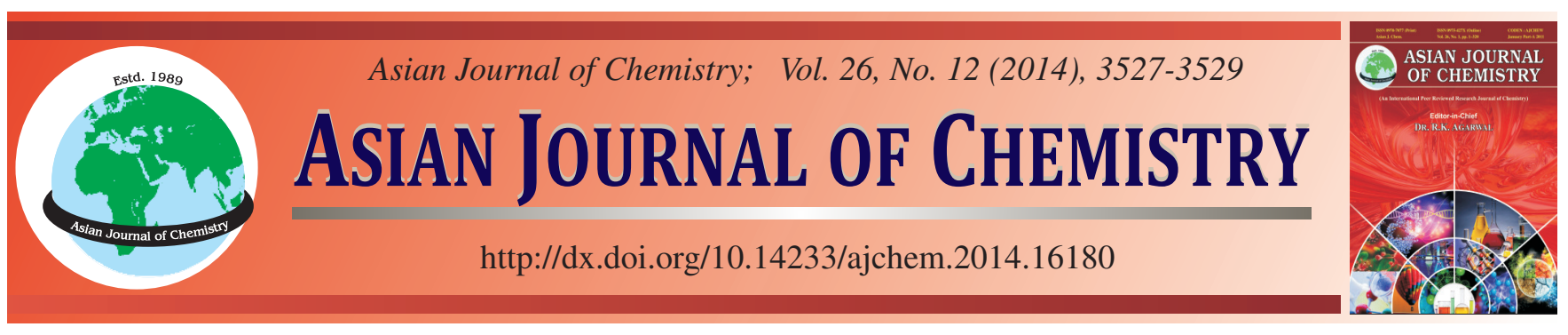

\title{
Kinetics and Mechanism Study of Oxidation of 2,3-Diaminopropionic Acid by Diperiodatocuprate(III) in Alkaline Medium
}

\author{
Changying Song ${ }^{*}$, Lei Zhang, Ziyu Qi and Shigang Shen
}

College of Chemistry and Environmental Science, Hebei University, No. 180 Wusidong Road, Baoding City 071002, Hebei Province, P.R. China *Corresponding author: Tel/Fax: +86 312 5079386; E-mail: scy@hbu.edu.cn

The oxidation of 2,3-diaminopropionic acid (APA) by diperiodatocuprate(III) was studied spectrophotometrically between $298.2 \mathrm{~K}$ and $313.2 \mathrm{~K}$ in alkaline medium. The oxidation rate law was obtained : $\mathrm{k}_{\mathrm{obs}}=2 \mathrm{kK}_{1}\left[\mathrm{OH}^{-}\right][\mathrm{APA}] /\left(\mathrm{K}_{1}\left[\mathrm{OH}^{-}\right]+\left[\mathrm{H}_{2} \mathrm{IO}_{6}{ }^{2-}\right]\right)$. A reaction mechanism including a pre-equilibrium step was proposed. Activation parameters and the rate constants of the rate-determining step are calculated.

Keywords: Diperiodatocuprate(III), 2,3-Diaminopropionic acid, Kinetics and mechanism.

\section{INTRODUCTION}

Copper(III), in a higher oxidation state can be stabilized by chelation with suitable polydentate ligands, such as diperiodatocuprate(III) anion ${ }^{1-3}$. Diperiodatocuprate(III) anion can be used for the titrimetric determination of some reducing sugars, organic acids ${ }^{4}$. The oxidation of organic compounds by diperiodatocuprate(III) anion has been studied ${ }^{5,6}$. However, the oxidation reaction rate law and reaction mechanism were different because of the different reaction system. So the kinetics and mechism for oxidation of 2,3-diaminopropionic acid (APA) by diperiodatocuprate(III) anion was studied.

\section{EXPERIMENTAL}

Solutions of diperiodatocuprate(III) anion and 2,3-diaminopropionic acid are prepared freshly. The stock solution of diperiodatocuprate(III) anion in alkaline medium is prepared and standardized by the method reported earlier ${ }^{6,7}$. The concentration of $\mathrm{Cu}$ (III) is derived by its absorption at $\lambda=415 \mathrm{~nm}$. The ionic strength, $\mu=1.0 \mathrm{~mol} / \mathrm{L}$, is maintained by adding $\mathrm{KNO}_{3}$ solution and the $\mathrm{pH}$ value is regulated with $\mathrm{KOH}$ solution. All reagents are of A.R. grade. All solutions are prepared with twice distilled water. TU-1900 spectrophotometer (Beijing) and Refrigerated Circulator baths(Beijing) are all used for kinetics study.

Kinetics method: All kinetics measurements were carried out under pseudo-first order conditions. Solution $(2 \mathrm{~mL})$ containing definited $[\mathrm{Cu}(\mathrm{III})],\left[\mathrm{OH}^{-}\right],\left[\mathrm{IO}_{4}^{-}\right]$and ionic strength $\mu$ and 2,3-diaminopropionic acid solution $(2 \mathrm{~mL})$ of appropriate concentration were transferred separately to the upper and lower branch tubes of a type two-cell reactor. After it was thermally equilibrated at desired temperature in thermobath, the two solutions were mixed well and transferred into a $1 \mathrm{~cm}$ thick glass cell immediately with a constant temperature cellholder. The reaction process was monitored automatically by recording the disappearance of $\mathrm{Cu}(\mathrm{III})$ with time $(t)$ at 415 $\mathrm{nm}$ with a TU-1900 spectrophotometer. All other species did not absorb significantly at this wavelength.

Product analysis and stoichiometry: Solutions having known concentrations of $\mathrm{Cu}$ (III) was mixed with an excess of 2,3-diaminopropionic acid. After completion of the reaction, the product was transformed into a precipitate 2,4-dinitrophenyl drazine derivative. So formaldehyde is one of the product of this redox reaction. $\mathrm{NH}_{4}{ }^{+}$was identified as another product using Nessler's reagent.

\section{RESULTS AND DISCUSSION}

Evaluation of pseudo-first order rate constants: Under the conditions of $[\mathrm{APA}]_{0} \gg>[\mathrm{Cu}(\mathrm{III})]_{0}$. The plots of $\ln \left(\mathrm{A}_{\mathrm{t}}-\mathrm{A}_{\infty}\right)$ versus time are lines, indicating the reaction is first order with respect to $[\mathrm{Cu}(\mathrm{III})]_{0}$, where $\mathrm{A}_{\mathrm{t}}$ and $\mathrm{A}_{\infty}$ are the absorbance at time $t$ and at infinite time, respectively. The pseudo-first-order rate constants $\mathrm{k}_{\mathrm{obs}}$ are calculated by the method of least squares $(r \geq 0.999)$. To calculate $k_{\text {obs }}$ generally 8-10 $\mathrm{A}_{\mathrm{t}}$ values within three times the half-life are used. $\mathrm{k}_{\mathrm{obs}}$ values of the three independent experiments are averaged at least and reproducibility is within $\pm 5 \%$.

Rate dependence on [APA]: At fixed [Cu(III)], $\left[\mathrm{OH}^{-}\right]$, $\left[\mathrm{IO}_{4}^{-}\right]$and temperature. $\mathrm{k}_{\mathrm{obs}}$ values increased with the increase of [APA].The plots of $\mathrm{k}_{\mathrm{obs}}$ versus [APA] are straight lines which though the grid origin, so it indicates that the reaction is first order in [APA] (Table-1). 


\begin{tabular}{|c|c|c|c|c|c|}
\hline \multirow{3}{*}{ Temperature $(\mathrm{K})$} & \multicolumn{4}{|c|}{$\begin{array}{c}\text { TABLE }-1 \\
\mathrm{k}_{\text {obs }}\left(\mathrm{s}^{-1}\right) \text { VARYING WITH DIFFERENT [APA] AT DIFFERENT TEMPERATURES }\end{array}$} & \\
\hline & \multicolumn{5}{|c|}{ Concentration (mol/L) } \\
\hline & 0.06 & 0.08 & 0.1 & 0.2 & 0.3 \\
\hline 298.2 & 0.01394 & 0.01789 & 0.02155 & 0.04212 & 0.06370 \\
\hline 303.2 & 0.02164 & 0.02653 & 0.03330 & 0.06780 & 0.08900 \\
\hline 308.2 & 0.03000 & 0.03850 & 0.04543 & 0.08900 & 0.13660 \\
\hline 313.2 & 0.03240 & 0.04434 & 0.05289 & 0.11070 & 0.14650 \\
\hline
\end{tabular}

Rate dependence on $\left[\mathrm{OH}^{-}\right]$: At fixed $[\mathrm{Cu}(\mathrm{III})],\left[\mathrm{IO}_{4}^{-}\right]$, [APA] and temperature. $\mathrm{k}_{\mathrm{obs}}$ values increased with the increase of $\left[\mathrm{OH}^{-}\right]$. The plot of $1 / \mathrm{k}_{\mathrm{obs}}$ versus $1 /\left[\mathrm{OH}^{-}\right]^{-}$is line (Table-2).

TABLE-2
\begin{tabular}{cccccc}
\multicolumn{6}{c}{$\mathrm{k}_{\text {obs }}\left(\mathrm{s}^{-1}\right)$ VARYING WITH THE DIFFERENT $\left[\mathrm{OH}^{-}\right]$} \\
\hline $\mathrm{C}(\mathrm{mol} / \mathrm{L})$ & 0.01 & 0.02 & 0.03 & 0.04 & 0.05 \\
\hline $10^{3} \mathrm{k}_{\text {obs }}$ & 4.4 & 7.47 & 10.3 & 12.68 & 14.98 \\
\hline$[\mathrm{Cu}(\mathrm{III})]=4.5 \times 10^{-5} \mathrm{~mol} / \mathrm{L},\left[\mathrm{IO}_{4}^{-}\right]$ & $=2 \times 10^{-3} \mathrm{~mol} / \mathrm{L},[\mathrm{APA}]=0.08$ \\
$\mathrm{~mol} / \mathrm{L}, \mathrm{T}=298.2 \mathrm{~K}, \mu=1.0 \mathrm{~mol} / \mathrm{L}$
\end{tabular}

Rate dependence on $\left[\mathrm{IO}_{4}^{-}\right]$: At fixed $[\mathrm{Cu}(\mathrm{III})],\left[\mathrm{OH}^{-}\right]$, [APA] and temperature. kobs values decreased with the increase of $\left[\mathrm{IO}_{4}^{-}\right]$. The plots of $1 / \mathrm{k}_{\text {obs }}$ versus $\left[\mathrm{IO}_{4}^{-}\right]$are straight lines with a positive intercept indicating the order with respect to $\left[\mathrm{IO}_{4}^{-}\right]$were found to be fractional order (Table-3).

Free radical detection and the mechanism: In the alkaline medium, the electric dissociation equilibrium of telluric acid is given earlier ${ }^{8-10}\left(\right.$ here $\left.\mathrm{pK}_{\mathrm{w}}=14\right)$.

$$
\begin{array}{ll}
2 \mathrm{IO}_{4}{ }^{-}+2 \mathrm{OH}^{-} \rightleftharpoons \mathrm{H}_{2} \mathrm{I}_{2} \mathrm{O}_{10}{ }^{4-} & \log \beta_{1}=15.05 \\
2 \mathrm{IO}_{4}^{-}+2 \mathrm{OH}^{-}+\mathrm{H}_{2} \mathrm{O} \rightleftharpoons \mathrm{H}_{3} \mathrm{IO}_{6}{ }^{2-} & \log \beta_{1}=6.21 \\
\mathrm{IO}_{4}{ }^{-}+2 \mathrm{OH} \rightleftharpoons \mathrm{H}_{2} \mathrm{IO}_{6}{ }^{3-} & \log \beta_{1}=8.67
\end{array}
$$

The distribution of all species of tellurate in aqueous alkaline solution can be calculated from eqns 1,2 and 3. In alkaline medium used in the experiment, the main species of $\mathrm{IO}_{4}{ }^{-}$is $\mathrm{H}_{2} \mathrm{IO}_{6}{ }^{3-}$. So eqns 4 and 5 can be obtained.

$$
\begin{aligned}
& {\left[\mathrm{H}_{2} \mathrm{IO}_{6}{ }^{3}\right]_{\mathrm{e}}=\mathrm{f}\left(\left[\mathrm{OH}^{-}\right]\right)\left[\mathrm{IO}^{-}\right]_{\mathrm{tot}}} \\
& \mathrm{f}\left(\left[\mathrm{OH}^{-}\right]\right)=\beta_{3}\left[\mathrm{OH}^{-}\right]^{2} /\left(1+\beta_{2}\left[\mathrm{OH}^{-}\right]+\beta_{3}\left[\mathrm{OH}^{-}\right]^{2}\right)
\end{aligned}
$$

The fractional and inverse fractional order dependence of $\mathrm{k}_{\mathrm{obs}}$ on $\left[\mathrm{OH}^{-}\right]$and $\left[\mathrm{IO}^{-}\right]$, respectively indicate that $\mathrm{OH}^{-}$ions would be present in a preequilibrium and then $\left[\mathrm{Cu}\left(\mathrm{H}_{2} \mathrm{IO}_{6}\right)_{2}{ }^{5-}\right]$ loses a $\mathrm{H}_{2} \mathrm{IO}_{6}{ }^{3-}$ ligand from its coordination sphere forming a transition complex $\left[\mathrm{Cu}\left(\mathrm{HIO}_{6}\right)\right]^{3-}$, which is the activity species of the $\mathrm{Cu}$ complex.

The addition of acrylonitrile or acrylamide to the reaction mixture under nitrogen atmosphere the polymerization happened in the reaction, showing free radical producted in the reaction. In our study, we also believe a similar type of a two-step oneelectron transfer mechanism. According to the above experimental facts, we bring forward the mechanism of the reaction below:

$$
\begin{aligned}
& {\left[\mathrm{Cu}\left(\mathrm{H}_{2} \mathrm{IO}_{6}\right)_{2}\right]^{5-}+\mathrm{OH}^{-} \stackrel{\mathrm{k}_{1}}{\rightleftharpoons}\left[\mathrm{Cu}\left(\mathrm{HIO}_{6}\right)\right]^{3-}+\mathrm{H}_{2} \mathrm{IO}_{6}{ }^{3--}+\mathrm{H}_{2} \mathrm{O}(6)} \\
& {\left[\mathrm{Cu}\left(\mathrm{HIO}_{6}\right)\right]^{3-}+\mathrm{CH}_{2}\left(\mathrm{NH}_{3}\right) \mathrm{CH}\left(\mathrm{NH}_{3}\right) \mathrm{COO}^{-} \stackrel{\mathrm{k}}{\text { slow }} \mathrm{CH}^{\circ} \mathrm{CH}} \\
& \left(\mathrm{NH}_{3}\right) \mathrm{COO}^{-}+\mathrm{Cu}(\mathrm{II})+\mathrm{NH}_{3}+2 \mathrm{OH}^{-}+\mathrm{H}_{2} \mathrm{IO}_{6}{ }^{3-} \text { (7) } \\
& \mathrm{Cu}(\mathrm{IIII})+4 \mathrm{OH}^{-}+\mathrm{CH}^{\circ} \mathrm{CH}\left(\mathrm{NH}_{3}\right) \mathrm{COO}^{-} \stackrel{\text { fast }}{\longrightarrow} \mathrm{Cu}(\mathrm{II}) \\
& +2 \mathrm{CHO}+\mathrm{NH}_{3}+2 \mathrm{H}_{2} \mathrm{O}+\mathrm{CO}_{2}
\end{aligned}
$$

Eqn. 6 is a pre-equilibrium. Eqn 7 belongs to electrontransfer reaction, whose reaction rate is generally slower, so eqn. 7 is the rate-determining step.

$$
-\mathrm{d}[\mathrm{Cu}(\mathrm{III})]_{t} / \mathrm{dt}=\mathrm{k}\left[\mathrm{Cu}\left(\left(\mathrm{HIO}_{6}\right)^{3-}\right][\mathrm{APA}]\right.
$$

where $[\mathrm{Cu}(\mathrm{III})]_{\mathrm{t}}$ stands for any kind of form of $\mathrm{Cu}(\mathrm{III})$ complexes which exited in equilibrium.

Then we get:

$$
\begin{gathered}
\mathrm{k}_{\mathrm{obs}}=\frac{2 \mathrm{kK}_{1}\left[\mathrm{OH}^{-}\right][\mathrm{APA}]}{\mathrm{K}_{1}\left[\mathrm{OH}^{-}\right]+\left[\mathrm{H}_{2} \mathrm{IO}_{6}^{2-}\right]} \\
\mathrm{k}_{\mathrm{obs}}=\frac{2 \mathrm{kK}_{1}\left[\mathrm{OH}^{-}\right][\mathrm{APA}]}{\mathrm{K}_{1}\left[\mathrm{OH}^{-}\right]+\mathrm{f}\left(\left[\mathrm{OH}^{-}\right]\right)\left[\mathrm{IO}_{4}^{-}\right]}
\end{gathered}
$$

\begin{tabular}{|c|c|c|c|c|c|}
\hline \multicolumn{6}{|c|}{$\begin{array}{c}\text { TABLE-3 } \\
10^{3} \mathrm{k}_{\mathrm{obs}}\left(\mathrm{s}^{-1}\right) \text { VARYING WITH THE DIFFERENT }\left[\mathrm{IO}_{4}^{-}\right]\end{array}$} \\
\hline \multirow{2}{*}{ Temperature $(\mathrm{K})$} & \multicolumn{5}{|c|}{ Concentration (mol/L) } \\
\hline & 0.8 & 1.0 & 2.0 & 3.0 & 4.0 \\
\hline 298.2 & 0.03644 & 0.03030 & 0.01540 & 0.01038 & 0.008076 \\
\hline 303.2 & 0.05545 & 0.04876 & 0.02498 & 0.01570 & 0.012890 \\
\hline 308.2 & 0.07543 & 0.06654 & 0.03219 & 0.02349 & 0.017980 \\
\hline 313.2 & 0.08878 & 0.07234 & 0.03643 & 0.02314 & 0.020980 \\
\hline
\end{tabular}

From eqn. 10 and 11 , the rate constants of rate-determining step at different temperature and active parameters for the redox reaction were calculated and listed in Table- 4 .

\section{Conclusion}

The oxidation of 2,3-diaminopropionic acid (APA) by diperiodatocuprate(III) is studied. The active parameters (Table-1) was obtained through the kinetics studies. The redox products were also identified as $\mathrm{HCHO}, \mathrm{NH}_{3}$ and $\mathrm{CO}_{3}{ }^{2-}$. So the breakage of $\mathrm{C}-\mathrm{C}$ bonds of the organic compounds containing $\mathrm{NH}_{3}$ in the ortho-position will be happened by the oxidation of dihydroxyditellutocuperate(III) anion.

TABLE-4

RATE CONSTANTS $(\mathrm{k})$ AND ACTIVATION PARAMETERS OF THE RATE-DETERMINING STEP (T=298.2 K)

\begin{tabular}{ccccc|ccc}
\hline $\mathrm{T}(\mathrm{K})$ & 298.2 & 303.2 & 308.2 & 313.2 & $\mathrm{Ea}\left(\mathrm{KJ} \mathrm{mol}^{-1}\right)$ & $\Delta \mathrm{H}^{\#}\left(\mathrm{KJ} \mathrm{mol}^{-1}\right)$ & $\Delta \mathrm{S}^{\#}\left(\mathrm{~J} \mathrm{~mol}^{-1} \mathrm{~K}^{-1}\right)$ \\
\hline $\mathrm{k}\left(\mathrm{mol}^{-1} \mathrm{~L} \mathrm{~s}^{-1}\right)$ & 1.2 & 2.1 & 3.3 & 4.0 & 67.68 & 65.20 & -24.26 \\
\hline
\end{tabular}




\section{REFERENCES}

1. A. Kumar, Vaishali and P. Ramamurthy, Int. J. Chem. Kinet., 32, 286 (2000).

2. N. Weijun, Z. Yan, H. Kecheng, T. Changlun and Y. Hangsheng, Int. J. Chem. Kinet., 28, 899 (1996).

3. A. Balikungeri and M. Pelletier, Inorg. Chim. Acta, 29, 141 (1978).

4. P.K. Jaiswal and D.L. Yadava, Indian J. Chem., 11, 837 (1973).

5. K.K. Sen Gupta, B.K. Nandy and S. Sen Gupta, J. Org. Chem., 59, 858 (1994).
6. A. Kumar, P. Kumar and P. Ramamurthy, Polyhedron, 18, 773 (1999).

7. A. Balikungeri, M. Pelletier and D. Monnier, Inorg. Chim. Acta, 22, 7 (1977).

8. J. Aveston, J. Chem. Soc. A, 273 (1969).

9. C.E. Crouthamel, H.V. Meek, D.S. Martin and C.V. Banks, J. Am. Chem. Soc., 71, 3031 (1949).

10. C.E. Crouthamel, A.M. Hayes and D.S. Martin, J. Am. Chem. Soc., 73, 82 (1951). 